\title{
Relationship between Alcohol Consumption and Violent Offending: Personality as a Contributing Factor
}

\author{
Martina Lotar Rihtarić ${ }^{1}$, Ivana Vrselja² ${ }^{2}$ Anita Jandrić Nišević ${ }^{3}$ \\ ${ }^{1}$ Department of Criminology, Faculty of Education and Rehabilitation Sciences University \\ of Zagreb, Zagreb, Croatia, ${ }^{2}$ Catholic University of Croatia, Zagreb, Croatia, ${ }^{3}$ Department \\ of Criminology, Faculty of Education and Rehabilitation Sciences University of Zagreb, \\ Zagreb, Croatia
}

\begin{abstract}
Strong evidence exists that alcohol consumption and violent offending are linked, and the "common cause" model suggests that this link results from shared risk factors. To test this model and further explore the connection between alcohol consumption and violent offending, the present study used regression analysis to examine possible relationships among alcohol consumption, violent offending and personality characteristics (extraversion, neuroticism and psychoticism) in 1464 male prisoners aged 17 to 79 years who entered in Croatian prison system in 2013. and were evaluated in the Center for Diagnostics in Zagreb. The results suggest that alcohol consumption and violent offending share some personality risk factors, and that alcohol consumption mediates the relationship between personality and violent offending. These results are discussed within the framework of the common cause model, providing more detailed insights into the complex relationship among personality, alcohol consumption, and violent offending.
\end{abstract}

Key words: alcohol consumption, personality, violent offending

Copyright (C) 2015 KBCSM, Zagreb

e-mail: alcoholism.kbcsm@gmail.com•www.http//hrcak.srce.hr/acoholism

\section{Introduction}

Numerous studies have identified alcohol consumption as a risk factor for violent offending. McMurran and Cusens [1] found that nearly three-quarters of 126 British prisoners convicted for violent offences reported they were drunk at the time. Studies in Aus-

\section{Correspondence to:}

Martina Lotar Rihtarić

Edukacijsko-rehabilitacijski fakultet, Odsjek za kriminologiju Borongajska c. $83 \mathrm{f}$

martina.lotar.rihtaric@erf.hr tralia suggest that $23-73 \%$ of all assaults are committed when the attacker is drunk $[2,3]$. A large-scale national study in that country found that in 2007, half of all offenders detained by police for disorder and violent offences had consumed alcohol in the 48 hours prior to arrest [4]. In the US, 35\% of victims of violent attacks who were able to assess whether their attacker had been using alcohol, believed the offender had been drinking at the time of the attack. Half of victims of interpersonal violence in England and Wales 
reported the perpetrator to be under the influence of alcohol at the time of assault [5].

Several models have been offered to explain the well-documented relationship between alcohol and violence, with most models proposing a direct link. Some of these "direct link" models include the psychopharmacological effects of alcohol as potential mediators of violent offences, such as impairment of cognitive processes that affect judgment, behavior inhibition and interpersonal communication [6]. In contrast to these widely accepted direct link models, "common cause" models propose that alcohol consumption and violent offending are related indirectly via risk factors that they have in common $[7,8]$. These shared risk factors include some dimensions of personality, with psychoticism $(\mathrm{P})$, extraversion $(\mathrm{E})$, and neuroticism $(\mathrm{N})$ invoked most often. These three dimensions are included in Eysencks' theory of personality [9], which provides a useful scheme for exploring personality antecedents of divergent antisocial behavior. In Eysencks' theory, $\mathrm{P}$ is anchored at one end by aggressiveness and divergent thinking and at the other end by empathy and caution. This trait is so named because individuals with a high $\mathrm{P}$ level are significantly more vulnerable to psychotic disorders than those with a low P level. E is represented on a bipolar scale anchored at one end by sociability and stimulation-seeking, and at the other end by social reticence and stimulation avoidance. $\mathrm{N}$ is anchored at one end by emotional instability and spontaneity, and at the other end by reflection and deliberateness. This trait is so named because individuals with a high $\mathrm{N}$ level are more vulnerable to anxiety-based problems.

Individuals with a high $\mathrm{P}$ level are predisposed to developing antisocial behavior [9], and those with high levels of both $\mathrm{P}$ and $\mathrm{E}$ are predisposed to developing antisocial behavior involving aggression. If such an individual also has a high $\mathrm{N}$ level, their behavior may exhibit emotional, irrational characteristics under some circumstances [10]. Higher $\mathrm{P}$ levels are strongly related to alcohol consumption [11], and several studies have shown a link between higher E levels and alcohol consumption in non-alcoholics and alcoholics alike [12-14]. $\mathrm{N}$ appears to correlate positively with alcohol consumption specifically among those with clinically significant alcohol problems [15-17]. Individuals who consume alcohol heavily may develop high levels of $\mathrm{N}$ and anxiety to buffer the negative affect associated with alcohol dependence [18].

Numerous studies in Anglo-Saxon countries showed that personality dimensions contribute to the explanation of alcohol consumption and violent offending. However, most of these studies explored these relationships separately, that is, only few of them explored relationship between all three variables at the same time. In addition, there is a knowledge gap in the literature regarding some postulates of common cause model that explains relationship between alcohol consumption and violent offending. Common cause model clearly states that personality is a risk factor for both alcohol consumption and violent offending. In this line, it seems reasonable to assume that alcohol consumption mediates the association between personality and violent offending. However, this assumption has not been clearly stated in common cause model, nor there are studies which tested it.

The present study aimed to improve our understanding of the relationship between alcohol consumption and violent offending, 
based on a common cause model. The work is based on the proposal that personality is a common risk factor for both violent offending and alcohol consumption. This proposal led us to examine three hypotheses in a sample of mostly non-alcoholic violent offenders. First, we hypothesized that personality - specifically, higher levels of P, E and N - would significantly predict violent offending. Second, we hypothesized that in our mostly non-alcoholic sample, higher levels of $\mathrm{P}$ and $\mathrm{E}$ would predict alcohol consumption, whereas levels of $\mathrm{N}$ would not. Third, we hypothesized that alcohol consumption would mediate a link between personality and violent offending: higher levels of $\mathrm{P}$ and $\mathrm{E}$ would increase alcohol consumption, which would lead in turn to violent offending. We did not expect levels of $\mathrm{N}$ to mediate this role since we did not expect it to affect alcohol consumption in our mostly non-alcoholic sample.

\section{Subjects and methods}

\section{Subjects}

The sample consisted of all prisoners who entered in Croatian prison system during 2013. and were evaluated in the Center for Diagnostics in Zagreb, Croatia. The Center for Diagnostics operates independently within the Prison System Directorate of the Croatian Ministry of Justice. This includes all prisoners who received a sentence longer than 6 months, if their sentence mandates psychiatric treatment, or if they were transferred from other penal systems to complete their sentence in the Croatian prison system because of international agreements or special laws. Prisoners were excluded if they were categorized as abstinent with respect to alcohol use (see below).
The study population included 1464 male and 89 female prisoners. All analyses are supposed to be conducted separately on male and female subsamples, but because of a small number of female prisoners, they were excluded from the sample. Male prisoners' age ranging from 17 to 79 years $(\mathrm{M}=37.72$, $\mathrm{SD}=11.91)$. Sentence lengths ranged from 3 months to 40 years $(\mathrm{M}=26.9$ months; $\mathrm{SD}=$ 33.74 months). The most frequent offences in this sample were drug abuse $(21 \%$ of prisoners), larceny or grand larceny (17.4\%), robbery $(10.2 \%)$, fraud $(7.3 \%)$, causing a traffic accident $(6.9 \%)$, murder $(5.6 \%)$, or some type of sexual offence $(5.5 \%)$.

\section{Data collection and prisoner classification by alcohol use}

This study was carried out with the approval of the Prison System Directorate of the Croatian Ministry of Justice. In collaboration with colleagues from Center for Diagnostics in Zagreb, different data for every prisoner were connected in one database. Prisoners were assessed at the Center for Diagnostics in Zagreb by an expert team comprising a social worker, lawyer, psychologist and physician. During this assessment, the team collected extensive data on the prisoner himself, including biographical data (age, marital status, education) and work experience; about the criminal offence, including type and details of the offence, especially whether he was aggressive while committing the criminal offence; sentence length; history of criminal activities, of addiction in general and specifically of alcohol abuse; his perspective on the offence and sentence; and diagnostic data, including the findings of psychiatric, cognitive and personality assessments. Personality was assessed using the Eysenck Personality Questionnaire - Revised/ 
Adult (see below). These data were collected through a combination of interviews (selfreport), psychological testing, and analysis of documents about prisoner history and activity prior to sentencing. Data for all prisoners were entered into a single database for the purposes of this study.

Based on lifetime alcohol abuse determined diagnostically based on self-report as well as documentary sources, the psychologist in the expert team assigned each prisoner to one of six categories:

1. non-drinker: generally does not ever drink because of attitude, religious beliefs or another kind of motive;

2. occasional drinker: drinks occasionally in social situations, but not on a regular basis;

3. regular drinker: drinks regularly, such as every day or every weekend, without any effect on psychological or social functioning;

4. excessive drinker without addiction: meets the DSM-IV criteria for alcohol abuse;

5. alcoholic: meets the DSM-IV criteria for alcohol addiction; or

6. abstinent: previously diagnosed with alcohol abuse or alcohol addiction, but has been stably abstinent in recent years.

Prisoners classified as "abstinent" ( $\mathrm{n}=$ 52) were excluded from the sample because it was impossible to ascertain when abstinence began relative to when the criminal behavior occurred.

\section{Personality assessment}

Personality traits were measured using the Eysenck Personality Questionnaire - Revised/ Adult (EPQ-R/A) [19]. This is a 106-item self-report questionnaire used to assess $\mathrm{N}$ (24 items), E (23 items) and P (32 items). The questionnaire also includes a Lie (dissimulation) scale (21 items), Criminality scale (34 items) and Addiction scale (32 items). Criminality and Addiction scales measure N, E and $\mathrm{P}$, and they also contain six new items. The response to all items on the questionnaire is yes or no. Cronbach's alpha for male samples in the original EPQ-R/A study was 0.78 for $\mathrm{P}, 0.88$ for $\mathrm{N}$, and 0.90 for $\mathrm{E}$ [23].

\section{Results}

\section{Descriptive analyses}

Table 1 summarizes descriptive baseline data and bivariate correlations between study variables. Offenders in our study scored below-average on $\mathrm{P}$ and $\mathrm{N}$ and above-average on $\mathrm{E}$ with respect to theoretical range on this scales. The prisoners were distributed among

Table 1. Means, Standard Deviations and Intercorrelations of Study Variables

\begin{tabular}{lccccc}
\hline & 1 & 2 & 3 & 4 & 5 \\
\hline 1. Psychoticism & - & .02 & $.36^{* *}$ & $.19^{* *}$ & $.11^{* *}$ \\
2. Extraversion & & - & $-.08^{* *}$ & -.03 & $-.07^{*}$ \\
3. Neuroticism & & & $-16^{* *}$ & $.15^{* *}$ \\
4. Alcohol consumption & & & & - & $.29^{* *}$ \\
5. Violent offending & & & & & - \\
\hline$M$ & 6.48 & 15.37 & 9.68 & \\
$S D$ & 3.40 & 4.15 & 5.17 & & \\
${ }^{*} p<.05 ;{ }^{* *} p<.01$ & & & &
\end{tabular}


the five categories of alcohol users as follows: occasional drinkers, $50.7 \%$; non-drinkers, $21.2 \%$; regular drinkers, $10.1 \%$; excessive drinkers, $10.7 \%$; and alcoholics, 7.6\%. One quarter of prisoners ( $\mathrm{n}=378,25.8 \%$ ) were violent when they committed their offence.

The results in Table 1 indicate that psychotic offenders in our population were more neurotic, they consumed more alcohol, and they were more likely to have committed a violent offence. Extraverted prisoners were less neurotic and less likely to have committed a violent offence. Neurotic offenders consumed more alcohol and were more likely to have committed a violent offence. Together, these results indicate that alcohol consumption in this sample significantly and positively correlated with violent offending.

\section{Regression and mediation analyses}

In order to determine to what extent personality variables were significant predictors of both violent offending and alcohol consumption in our sample, we performed separate regressions in which the criterion variable was violent offending or alcohol consumption (Table 2). Consistent with our first hypothesis, all three personality factors were significant predictors of violent offending (Regression 1). Higher P and $\mathrm{N}$ levels predicted violent offending, while lower $\mathrm{E}$ levels predicted violent offending. In partial support of our second hypothesis, two of three personality factors were significant predictors of alcohol consumption (Regression 2): higher $\mathrm{P}$ and $\mathrm{N}$ levels predicted alcohol consumption. This result was somewhat surprising, since we expected that higher $\mathrm{P}$ and E levels would predict alcohol consumption, while $\mathrm{N}$ would not.

Alcohol consumption and violent offending
We performed a third regression to determine whether alcohol consumption predicts violent offending even after controlling for personality factors (Regression 3). This analysis was designed to determine whether personality factors has indirect effect on violent offending through alcohol consumption, that is, whether alcohol consumption mediates relationship between personality and violent offending This regression was performed by entering all personality factors and alcohol consumption simultaneously into the model for predicting violent offending. The results showed that, even after controlling for P, E and $\mathrm{N}$, alcohol consumption remained a significant predictor of violent offending.

$\mathrm{P}$ and $\mathrm{E}$ were no longer significant predictors of violent offending when they were included together with alcohol consumption in the model (Table 2). This suggests that alcohol consumption may significantly mediate the relationship between personality and violent offending. To test this possibility, we conducted two mediation analyses: one in which $\mathrm{P}$ was predictor and alcohol consumption was mediator, and another in which $\mathrm{N}$ was predictor and alcohol consumption was mediator. In both analyses, the other two personality factors were controlled for. These mediation analyses were carried out using the PROCESS macro, [20] which uses bootstrapping to generate inferences about indirect effects without the need to assume data normality. Bootstrapping involves repeatedly sampling from the complete data set and estimating the indirect effect in each resample data set. This process is repeated thousands of times to generate an empirical approximation of the distribution of an indirect effect, allowing estimation of confidence intervals (CI) for the effect. In our analyses, we used a conventional number of bootstrap resamples 
Table 2. Regression Analyses to Determine Whether Alcohol Consumption Predicts Violent Offending, and Whether Personality Factors Mediate this Relationship

\begin{tabular}{|c|c|c|c|c|}
\hline \multirow[t]{2}{*}{ Predictor } & \multicolumn{4}{|c|}{ Regression 1: Violent offending as criterion } \\
\hline & $\mathrm{B}$ & SE B & $\mathrm{p}$ & $\mathrm{EXP}(\mathrm{B})$ \\
\hline Psychoticism & .04 & .02 & .03 & 1.04 \\
\hline Extraversion & -.04 & .02 & .02 & .97 \\
\hline Neuroticism & .05 & .01 & .00 & 1.05 \\
\hline \multirow[t]{3}{*}{ Nagelkerke } & \multicolumn{4}{|c|}{.04} \\
\hline & \multicolumn{4}{|c|}{ Regression 2: Alcohol consumption as criterion } \\
\hline & $\beta$ & SE $\beta$ & $\mathrm{p}$ & / \\
\hline Psychoticism & .16 & .01 & .00 & \\
\hline Extraversion & -.03 & .01 & .30 & \\
\hline Neuroticism & .10 & .01 & .00 & \\
\hline \multirow[t]{3}{*}{$R^{2}$} & \multicolumn{4}{|c|}{.04} \\
\hline & \multicolumn{4}{|c|}{ Regression 3: Violent offending as criterion } \\
\hline & B & SE B & $\mathrm{p}$ & $\mathrm{EXP}(\mathrm{B})$ \\
\hline Psychoticism & .02 & .02 & .43 & 1.02 \\
\hline Extraversion & -.03 & .02 & .09 & .97 \\
\hline Neuroticism & .04 & .01 & .01 & 1.04 \\
\hline Alcohol consumption & .54 & .06 & .00 & 1.72 \\
\hline Nagelkerke & \multicolumn{4}{|c|}{.14} \\
\hline
\end{tabular}

Table 3. Bootstrap Analysis of the Indirect Effects of Personality Factors on Violent Offending Through Alcohol Consumption

\begin{tabular}{lcccc}
\hline \multirow{2}{*}{ Personality factor } & Point estimate & SE & BCa 95\% CI & BCa 95\% CI \\
\cline { 4 - 5 } & .03 & .01 & lower & upper \\
\hline Psychoticism & .01 & .00 & .02 & .04 \\
Neuroticism & .00 & .00 & .02 \\
\hline
\end{tabular}

Note. BCa - bias-corrected and accelerated. Confidence intervals (CI) do not contain a zero and therefore indicate significant indirect effects 
(5.000) to generate a 95\% CI. If the 95\% CI does not include zero, we can conclude with $95 \%$ confidence that the indirect effect is significant [21, 22].

Bootstrap analysis showed that alcohol consumption significantly mediated the relationship between $\mathrm{P}$ and violent offending, as well as the relationship between $\mathrm{N}$ and violent offending (Table 3). In other words, higher $\mathrm{P}$ or $\mathrm{N}$ levels predicted greater alcohol consumption, which in turn predicted violent offending. These results partially support our third hypothesis, since we expected that alcohol consumption would mediate the effects of $\mathrm{P}$ and $\mathrm{E}$, but not of $\mathrm{N}$, on violent offending.

\section{Discussion}

In this study, we used a common cause model to examine the complex relationship among personality, alcohol consumption and violent offending in a sample of mostly nonalcoholic violent offenders. High levels of P, $\mathrm{E}$ or $\mathrm{N}$ independently predicted violent offending, suggesting that all three personality dimensions contribute to such behavior. These results are in line with our hypotheses, Eysencks' personality theory and numerous studies of the relationship between personality and antisocial behavior [meta-analyzed in 23]. These results may be specific to prisoner populations, since a comparison of group of 100 delinquent inmates and a group of 100 university students found that only the former group presented a combination of high levels of $\mathrm{P}, \mathrm{E}$ and $\mathrm{N}$ associated with offending [24]. Future, large studies should clarify whether the relationship between personality and antisocial behavior differs in incarcerated and non-incarcerated antisocial individuals.

We found that higher $\mathrm{P}$ and $\mathrm{N}$ levels predicted alcohol consumption, partially sup- porting our second hypothesis that $\mathrm{P}$ and $\mathrm{E}$ would predict alcohol consumption, while $\mathrm{N}$ would not. Our hypothesis was based on studies in non-incarcerated subjects showing that $\mathrm{E}$ predicted both occasional and problematic alcohol consumption, while $\mathrm{N}$ predicted only clinically significant alcohol consumption problems [15-17]. Since our sample comprised mostly non-alcoholic, occasional alcohol drinkers, we reasoned that $\mathrm{N}$ would not be a significant predictor of alcohol consumption. The discrepancy between our results and our hypothesis may reflect the fact that our study population was offenders, who usually are significantly more psychotic and neurotic than non-offenders, as well as slightly but not significantly more extraverted [25-28].

The present study contributes to the literature by strengthening the evidence that personality dimensions and alcohol consumption likewise contribute to violent offending. It also contributes by providing some of the first evidence from a relatively large sample that alcohol consumption mediates the relationship between personality and violent offending. In partial support of our hypothesis, we found that higher levels of $\mathrm{P}$ and $\mathrm{N}$, but not $\mathrm{E}$, predicted greater alcohol consumption, which in turn predicted violent offending. These results are consistent with previous reports that offenders with high P levels show impulsivity, aggressiveness, and coldness in interpersonal relations [29], which can lead to both alcohol consumption and violent offences. Our results are also consistent with studies showing that alcohol consumption can be a coping strategy to escape negative internal experiences such as anxiety [30-33], which is associated with neuroticism. This alcohol consumption then inhibits selfcontrol and can lead to violent offences. 
The results of this study should be interpreted with caution given at least two major methodological limitations. First, we did not examine possible confounding due to age of beginning with violent behavior. Antisocial behavior appears to be strongly related to $\mathrm{P}$ in young and old individuals, whereas it appears to be related to E primarily in younger individuals and to $\mathrm{N}$ primarily in older people [34]. Future studies should perform subgroup analysis by age at offence. Second, we did not compare our prisoner population with a non-incarcerated population of violent or non-violent delinquents who did not receive prison sentences. Future studies should perform parallel comparisons between prisoner and non-prisoner populations to assess if the experimental results could be applied to general population.

Despite these limitations, the present study has at least one methodological advantage over many previous studies in the literature. Alcohol consumption in the present work was assessed diagnostically by experts based on self-report together with documen-

\section{References}

1. McMurran M, Cusens B. Alcohol and violent and nonviolent acquisitive offending. Addict Res Theory. 2005;13:439-443.

2. Briscoe S, Donnelly N. Temporal and regional aspects of alcohol-related violence and disorder. Alcohol studies 2001;1:77-98.

3. Doherty SJ, Roche AM. Alcohol and licensed premises: best practice in policing. A monograph for police and policy makers. Adelaide: Australasian Centre for Policing Research; 2003.

4. Adams K, Sandy L, Smith L, Triglone B. Drug use monitoring in Australia (DUMA): 2007 annual report on drug use among police detainees. Research and public policy series no. 93. Canberra: Australian Institute of Criminology; 2008. tary sources. Many previous studies relied solely on self-reported alcohol use. This can lead to bias because offenders tend to dissimulate to earn benefits or receive better treatment in prison.

In conclusion, this study suggests that the common cause model can clarify the complex relationships among personality, alcohol consumption and violent offending. Our data are consistent with the idea that alcohol consumption and violent offending are related through shared risk factors, among which are the personality dimensions $\mathrm{P}$ and N. Our findings may help guide the development of prison programs to address alcohol consumption and violent behavior.

\section{Acknowledgements}

This research was conducted with the consent and in cooperation with Head office of Prison System Directorate, Ministry of Justice of the Republic of Croatia.

\section{Conflict of interest}

None to declare

5. Room R. Alcohol in developing societies: a public health approach. Helsinki and Geneva: Finnish Foundation for Alcohol Studies and World Health Organization; 2003.

6. Boles SM, Miotto K. Substance abuse and violence: A review of the literature. Aggress Violent Behav. 2003;8:155-174.

7. Fergusson DM, Lynskey MT, Horwood LJ. Alcohol misuse and juvenile offending in adolescence. Addiction. 1996;91:483-494.

8. White HR, Gorman DM. Dynamics of the drugcrime relationship. In: LaFree $G$, ed. Criminal justice 2000 The nature of crime: Continuity and change. Washington, DC: U.S. Department of Justice; 2000. p. 151-218.

9. Eysenck HJ. Personality and the biosocial model of anti-social and criminal behavior. In: Raine A, 
Brennan P, Farrington D, Mednick S, eds. Biosocial bases of violence. New York: Plenum Press; 1997. p. 21-37.

10. Center DB, Jackson N, Kemp, D. A test of Eysencks antisocial behavior hypothesis employing 11-15-year-old students dichotomous for PEN and L. Pers. Individ. Dif. 2005;38:395-402.

11. George SM, Connor JP, Gullo MJ, Young RMcD. A prospective study of personality features predictive of early adolescent alcohol misuse. Pers. Individ. Dif. 2010;49: 204-209.

12. Hakulinen C, Elovainio M, Batty GD, Virtanen M, Kivimäki M, Jokela M. Personality and alcohol consumption: Pooled analysis of 72,949 adults from eight cohort studies. Drug Alcohol Depend. 2015;151:110-114.

13. Martsh CT, Miller, WR. Extraversion predicts heavy drinking in college students. Pers. Individ. Dif. 1997;23:153-155.

14. McCabe CT, Roesch SC, Aldridge-Gerry AA. "Have a drink, you'll feel better." Predictors of daily alcohol consumtion among extraverts: the mediational role of coping. Anxiety Stress Coping. 2013;26:121-135.

15. Baer JS. Student Factors: Understanding Individual Variation in College Drinking. J Stud Alcohol Suppl. 2002;14:40-53.

16. Chinnian RR, Taylor LR, Al-Subaie A, Sugumar A. A controlled study of personality patterns in alcohol and heroin abusers in Saudi Arabia. J Psychoactive Drugs. 1994; 26:85-88.

17. King AC, Errico AL, Parsons OA. Eysenck's personality dimensions and sex steroids in male abstinent alcoholics and nonalcoholics: an exploratory study. Biol. Psychol. 1995;39:103-113.

18. Cloninger CR, Sigvardsson S, Prybeck TR, Svrakic DM. Personality antecedents of alcoholism in a national area probability sample. Eur. Arch. Psychiatry Clin. Neurosci. 1995;245:239-244.

19. Eysenck HJ, Eysenck SBG. Priručnik za Eysenckove skale ličnosti [Manual for the Eysenck personality scales]. Jastrebarsko: Naklada Slap; 1994.

20. Hayes AF. PROCESS: A versatile computational tool for observed variable moderation, mediation, and conditional process modelling. 2012 [downloaded 2012 March 25] Available from: http:// www.afhayes.com/public/process2012.pdf.
21. Preacher KJ, Hayes AF. Asymptotic and resampling strategies for assessing and comparing indirect effects in multiple mediator models. Behav Res Methods. 2008;40:879-891.

22. Shrout PE, Bolger N. Mediation in Experimental and Nonexperimental Studies: New Procedures and Recommendations. Psychol. Methods. 2002;7:422-445.

23. Miller JD, Lynam DR. Structural models of personality and their relation to antisocial behavior: A meta-analytic review. Criminology. 2001;39:765798.

24. McGurk BJ, McDougall C. A new approach to Eysenck's theory of criminality. Pers. Individ. Dif. 1981;2:338-340.

25. Barack LI, Widom CS. Eysenck's theory of criminality applied to women awaiting trial. Br J Psychiatry. 1978;133:452-6.

26. Singh A. Study of personality and adjustment of criminals committing major and minor crimes. Indian J Criminology 1979;7:13-8.

27. Singh A. Study of extraversion, neuroticism and 59 AP J Psychological Medicine Vol. 15 (1) January-June 2014 Pabbathi, etal: Personality of offenders psychoticism in female criminals. Indian J Criminology 1980;8:94-9.

28. Gavin H. Criminological and Forensic Psychology. $1^{\text {st }}$ ed. Thousand Oaks, CA: SAGE Publications Inc; 2014.

29. Eysenck HJ. Addiction, Personality and Motivation. Hum Psychopharmacol. 1997;12:79-87.

30. Mezquita L, Stewart SH, Ruipérez MA. Bigfive personality domains predict internal drinking motives in young adults. Pers. Individ. Dif. 2010;49:240-245.

31. Stewart SH, Devine, H. Relations between personality and drinking motives in young adults. Pers. Individ. Dif. 2000;29:495-511.

32. Neighbors C, Larimer ME, Geisner IM, Knee CR. Feeling Controlled and Drinking Motives Among College Students: Contingent Self-Estem as a Mediator. Self Identity. 2004;3:207-224.

33. Kopf Tamara, Galić S, Matešić K. The efficency of MMOI-2 validity scales in detecting malingering of mixed anxiety-depressive disorder. Alcohol Psychiatry Res 2016;52:33-49

34. Eysenck HJ, Gudjonsson GH. The causes and cures of criminality. New York: Plenum; 1989. 


\section{Odnos između konzumacije alkohola i činjenja nasilnih kaznenih djela: doprinos ličnosti}

Sažetak - Postoje snažni dokazi da su konzumacija alkohola i nasilna kaznena djela čvrsto povezani, a model "zajedničkog uzroka" sugerira da veza potječe od zajedničkih čimbenika rizika. Da bismo testirali ovaj model i dalje ispitali vezu između konzumacije alkohola i nasilnih kaznenih djela, u ovoj studiji koristili smo analizu regresije da bismo ispitali moguće veze između konzumacije alkohola, nasilnih kaznenih djela i elemenata osobnosti (ekstroverzija, neuroticizam, psihoticizam). Ispitivanje je provedeno na 1464 muška zatvorenika u dobi od 17-79 godina, koji su ušli u hrvatski zatvorski sustav u 2013.godini I koji su evaluirani u Centru za Dijagnostiku u Zagrebu. Rezultati sugeriraju da konzumacija alkohola i nasilna kaznena djela dijele neke rizične čimbenike glede osobnosti, te da konzumacija alkohola modificira utjecaj čimbenika osobnosti na nasilna kaznena djela. O rezultatima se diskutira u okviru modela zajedničkog uzorka, što daje detaljniji uvid u kompleksni odnos između osobnosti, konzumacije alkohola i nasilnih kaznenih djela.

Ključne riječi: konzumacija alkohola, osobnost, nasilna kaznena djela 